\title{
Characterization of the bacterioplankton community and the influencing factors in the upper reaches of the Han River basin
}

He Sun ( $\sim$ hesunhe@126.com )

Xi'an University of Technology https://orcid.org/0000-0001-9712-9406

Baozhu Pan

Xi'an University of Technology

Haoran He

Xi'an University of Technology

Gengnan Zhao

Xi'an University of Technology

Xiaoming Jiang

Xi'an University of Technology

Xu Han

Xi'an University of Technology

Hao Wang

Xi'an University of Technology

\section{Research Article}

Keywords: planktonic bacteria, the Qinling Mountains, mainstem and tributaries, community structure, environmental factors

Posted Date: May 26th, 2021

DOI: https://doi.org/10.21203/rs.3.rs-175622/v1

License: (c) (i) This work is licensed under a Creative Commons Attribution 4.0 International License. Read Full License 


\section{Abstract}

The upper reaches of the Han River are the source region of water for the Middle Route of China's South-to-North Water Diversion Project, mainly for household, industrial, and irrigation purposes. Planktonic bacteria are more sensitive than macroorganisms to water physical and chemical properties and play a critical role in biogeochemical processes in river ecosystems. In November 2017 and April 2018, a systematic and methodical survey was carried out to evaluate the water quality and bacterial communities, on the mainstem of the Han River and its five main tributaries. In this study, high-throughput sequencing technology has been employed to investigate the bacterioplankton community composition. The results indicated that: 1) Diversity increased downstream, especially in the upper reaches of the Han River. 2) The relative abundance of Actinobacteria increased with the increase of river length, while that of Bacteroidetes decreased slightly. 3) Five tributaries were found to be importance sources of taxa to the Han River, however in both months a large proportion of OTUs (37.84\% and $36.34 \%$, respectively) had unknown sources. 4) Finally, redundancy analysis (RDA) and Bioenv analysis showed that environmental parameters $\left(\mathrm{pH}, \mathrm{TN}, \mathrm{Cond}, \mathrm{NH}_{4}{ }^{+}-\mathrm{N}, \mathrm{DO}, \mathrm{NO}_{2}{ }^{-}-\mathrm{N}, \mathrm{Chl}-\mathrm{a}\right.$ and $\left.\mathrm{T}\right)$ had a great influence $(p \leq 0.05)$ on the bacterioplankton community. These research results are beneficial for the managing the ecological system, protecting the tributary biodiversity, and conserving the mainstem and tributaries of the Han River basin.

\section{Introduction}

Rivers are the main source of industrial, agricultural, and domestic water for humans, linking the water cycle and the recycling of carbon, nitrogen and phosphorus (Schultz et al. 2013, Adhikari et al. 2019). Among the critical components of river ecosystems, microbes play an important role in degrading the multi-resourced pollutants (Llirós et al. 2014, Sorokin et al. 2014). As an important producer and decomposer of aquatic ecosystems, bacterioplankton can remineralize elements making them available for primary producers (Wu et al. 2015). Moreover, the diversity of microorganisms is an important indicator in water quality evaluations, which could reflect the degree of water pollution (Findlay 2010).

Recently, the spatiotemporal variation of bacterioplankton composition has been demonstrated, which tends to have repeatable and predictable patterns in river ecosystems (Chen et al. 2019). The phyla Proteobacteria, Actinobacteria, Bacteroidetes, and Firmicutes dominantly constituted the bacterioplankton communities in rivers, as evidenced by $16 \mathrm{~S}$ rRNA gene-based high-throughput sequencing studies (Tamames et al. 2010, Jani et al. 2018). Further investigations continually showed that environmental parameters (e.g., temperature, $\mathrm{pH}$, and nutrient levels) regulated complex microbial communities (Hu et al. 2014, Staley et al. 2015). Temperature changes the abundance of various bacteria in the river by affecting the growth rate of the bacteria (Sieburth 1967) in the river and their motility (McCaulou et al. 1995). Nutrients could affect the bacterial communities in water by changing its composition and distribution via the "bottom-up effect" (Pérez \& Sommaruga 2006, Bouvy et al. 2011). Reversely, bacteria can also be influenced by the composition and abundance of predators (e.g., ciliates) (Nakano et al. 1998).

As the largest tributary of the Yangtze River, the upper reaches of the Han River are the major component of the Middle Route of China's South-toNorth Water Diversion Project. With the rapid development of the urban economy in the related area, the industrial wastewater and domestic sewage discharged from the upper reaches of the Han River may damage the health of people along the river. Therefore, it is highly desirable for us to understand the biodiversity of the upper reaches of the Han River. The unique geographical location and complex natural environment make the area rich in biological resources, such as macroinvertebrate (Cao et al. 2016, Wang et al. 2019). As a tributary of the Han River, the headwaters originate in the Qinling Mountains. Because of its limited water volume, it is particularly sensitive to changes in the surrounding environment. Therefore, the streams-related research has attracted intensive attentions (Adhikari et al. 2019). Recently, the Han River basin has undergone significant anthropogenic interference, ranging from agricultural, industrial, and urban aspects, that presents remarkable environmental impact on the lotic ecosystems (Li et al., 2009). As part of the ecosystem, studying the ecological distribution of microorganisms has important implications for the ecological balance of the Qinling Mountains and the sustainable development and utilization of bacterial resources.

Currently, research on the upstream reaches of the Han River and streams from the southern Qinling Mountains is mainly concentrated on the following two aspects: (1) most of the previous studies focused on larger organisms, such as macroinvertebrate (Wang \& Tan 2017, Li et al. 2019);

(2) only bacteria in the sediments were studied, and only denitrifying bacteria respond to the environment (Chen 2017), not the entire bacterial community. Moreover, the existing research has mainly focused on streams, while there have been few studies on both rivers and streams. Based on the important role of planktonic bacteria in river ecosystems, it is necessary to investigate bacterioplankton community in the main tributaries of the upper reaches of the Han River.

In November 2017 and April 2018, water quality and bacterioplankton along the Han River mainstem and its five main tributaries (Xushui River, Jinshui River, Yue River, Xun River and Jinqian River) were systematically investigated from the southern foot of the Qinling Mountains. The major objectives of the study were to (1) compare the diversity and structure of planktonic bacterial community along the Han River and its main tributaries, and (2) identify the dominant environmental variables influencing planktonic bacterial community. Besides, a more thorough understanding on the water environmental quality in Han River is much appreciated as it provides a reasonable basis for environmental monitoring and pollution prevention.

\section{Materials And Methods}


As the largest tributary of the Yangtze River, the Han River originates from the Bozhong Mountains and flows through Hanzhong city and Ankang city. It enters Hubei Province in Baihe County, with an upstream length of $956 \mathrm{~km}$ and a catchment area of 95,220 km². The basin is situated in a subtropical climate, the respective average annual air temperature and precipitation is $12-16^{\circ} \mathrm{C}$, and $700-1800 \mathrm{~mm}$ (Liu 2014 ). The wet season lasts from May to October, during which $80 \%$ of the annual precipitation falls. There are many tributaries in the upper reaches of the Han River. There are 68 rivers with a length of more than $50 \mathrm{~km}$ and 18 rivers with a length of more than $100 \mathrm{~km}$. According to the climatic characteristics, habitat types and human disturbance of different rivers, we chose five (Xushui River, Jinshui River, Yue River, Xun River and Jinqian River) of the main tributaries.

Water samples were randomly obtained from 7 sections along the Han River and 25 sections from the tributaries at two separate sampling occasions: in October-November 2017 and April-May 2018 (Fig. 1). There are 7 sections in the upper reaches of the Han River, 5 sections in each tributary (Xushui River, Jinshui River, Yue River, Xun River and Jinqian River) and 3 sample points in each section. The water samples of 3 sample points of each section are evenly mixed into one sample. So, 64 samples (3L) were collected at a depth of $50 \mathrm{~cm}$ in the center of the river using organic glass hydrophores with good lighting. All samples were amplified and sequenced to determine bacterial community composition.

The conductivity (Cond), water temperature (T), pH and dissolved oxygen (DO) were measured with a Hach HQ40D portable multiparameter analyzer; the turbidity (Turd) was measured with a Hach 2100Q portable turbidimeter; According to the Water and Wastewater Detection and Analysis Method (4th edition), the total phosphorus (TP), total nitrogen ( $\mathrm{TN})$, ammonia nitrogen $\left(\mathrm{NH}_{4}{ }^{+}-\mathrm{N}\right)$, nitrate nitrogen ( $\left.\mathrm{NO}_{3}{ }^{-} \mathrm{N}\right)$ and nitrite nitrogen $\left(\mathrm{NO}_{2}{ }^{-} \mathrm{N}\right)$ were determined. To prevent the dissolution of pigments caused by acidification, the content of chlorophyll-a (Chl-a) was determined in the water according to the Code for Investigation of Lake Eutrophication (2nd edition). Please refer to this article (zhao et al. 2020) for the determination of physical and chemical factors. For bacterioplankton community analyses, water samples $(3 \mathrm{~L})$ were transported to the laboratory in polyethylene bottles at $0-4{ }^{\circ} \mathrm{C}$ and then filtered through a $0.22-\mu \mathrm{m}$ Durapore membrane filter (diameter $25 \mathrm{~mm}$; Xinya, China) within 24 $\mathrm{h}$ to collect microbial cells. Filters were stored at $-80^{\circ} \mathrm{C}$ for later analysis.

\subsection{DNA extraction, amplification and sequencing}

Filters with the total DNA of the water samples were cut into small fragments. The extraction of the total DNA from filters was performed using the Bioteke Water DNA Kit (Beijing, China) according to the manufacturer's protocols. The V4-V5 regions of the 16S rRNA genes used for construction were amplified by PCR $\left(95^{\circ} \mathrm{C}\right.$ for $2 \mathrm{~min}$, followed by 25 cycles at $95^{\circ} \mathrm{C}$ for $30 \mathrm{~s}, 55^{\circ} \mathrm{C}$ for $30 \mathrm{~s}$, and $72{ }^{\circ} \mathrm{C}$ for $30 \mathrm{~s}$ and a final extension at $72{ }^{\circ} \mathrm{C}$ for 5 min) using the primers 515F (5'-GTGCCAGCMGCCGCGG-3') and 907R (5'-CCGTCAATTCMTTTRAGTTT-3') (Shan et al. 2015). PCR was performed in triplicate in $20 \mu \mathrm{L}$ mixtures containing $4 \mu \mathrm{L}$ of $5 \times$ FastPfuBuffer, $2 \mu \mathrm{L}$ of $2.5 \mathrm{mM}$ dNTPs, $0.8 \mu \mathrm{L}$ of each primer $(5 \mu \mathrm{M}), 0.4 \mu \mathrm{L}$ of FastPfu polymerase, and $10 \mathrm{ng}$ of template DNA. Amplicons were extracted from $2 \%$ agarose gels and purified with the AxyPrep DNA Gel Extraction Kit (Axygen Biosciences, USA) according to the manufacturer's instructions and quantified using QuantiFluor ${ }^{\mathrm{TM}}$-ST (Promega, USA). Purified amplicons were pooled in equimolar amounts and sequenced using the Illumina MiSeq platform.

\subsection{Statistical and bioinformatics analysis}

Raw FASTQ files were demultiplexed and then quality-filtered using QIIME1 according to the reported procedures (Liu et al. 2018). Subsequent analysis was proceeded using UPARSE (version 7.1) and RDP Classifier (Wang et al. 2007) against the Greengenes 16S rRNA database (McDonald et al. 2012). Since uneven sampling may affect statistical analyses, the sequence data was in each sample randomly resampled to the lowest number of reads (9544).

\subsection{Statistical analysis}

Chao 1 richness, the Shannon-Wiener index and Pielou's evenness based on the identified OTUs were estimated. The Mann-Whitney Utest was used to compare the alpha diversity between sampling months (Mo et al. 2018). Beta-diversity was represented by Bray-Curtis distance matrices generated based on the OTU table (Bray \& Curtis 1957). Principal component analysis (PCA) was used to analyze the difference in the environmental gradient between the sampling sections of the mainstream and tributaries of the Han River in different samples. Because the data is normally distributed, pearson correlations were calculated between dendritic distance and relative abundance of bacterial phyla in the mainstream. The dendritic distance ( $\mathrm{km}$ ), which is a measure of the cumulative length of the branching river network (river length) of two sampling sites, was calculated using the ArcGIS V10.6 software (Chen et al. 2019).

SourceTracker, a Bayesian approach (Knights et al. 2011), was performed to infer the extent to which the bacterial communities in the water samples from the five tributaries (source) could explain that in the main stream (sink). The tool was able to identify the proportion of the microbial community in the mainstream that came from its tributaries. Therefore, the source referred to the five tributaries, while the sink referred to the mainstream.

Redundancy analysis (RDA) was performed to explore the relationship between environmental parameters and the bacterioplankton community composition (OTU). Before analysis, detrended correspondence analysis (DCA) was employed, and the longest gradients generated from DCA were 
$<2$, which indicates that RDA is suitable in the present study ( $\mathrm{Li}$ et al. 2019). Before RDA, all environmental data ( $\mathrm{pH}, \mathrm{Cond}, \mathrm{T}, \mathrm{DO}, \mathrm{Turd}, \mathrm{TP}_{\mathrm{T}} \mathrm{TN}, \mathrm{NH}{ }_{4}^{+}-$ $\mathrm{N}, \mathrm{NO}_{3}{ }^{-}-\mathrm{N}, \mathrm{NO}_{2}-\mathrm{N}$ and $\mathrm{Chl}-a$ ) needed to be standardized, while biological data also needed Hellinger transformed. Environmental variables with variance inflation factors (VIFs) > 20 were removed to avoid collinearity among factors. Then, the function "envfit" was run with 999 permutations to select the significant parameters ( $\mathrm{pH}, \mathrm{TN}$, Cond, $\mathrm{NH}_{4}{ }^{+}-\mathrm{N}, \mathrm{DO}, \mathrm{NO}_{2}{ }^{-} \mathrm{N}, \mathrm{Chl}-\mathrm{a}$ and $\mathrm{T}$ ) (Liu et al. 2018). Finally, the significance testing was assessed by the "permutest" function based on 999 permutations. Bioenv analysis calculates spearman's rank correlation between Bray-Curtis distance matrices of bacterial community and Euclidian distance matrices of the environmental factors, and selects the best combination of environmental factors. Function 'Bioenv' in the R package 'Vegan' was also performed to identify the subsets of environmental factors that best predicted the bacterial community composition. With the exception of RDA, Pearson correlation and Bioenv analysis, all other analyses were performed with seasons separate. All statistical analyses were performed using R programming (version 3.6.2).

\section{Results}

\subsection{Water chemical analysis}

The basic physical and chemical data of the different water samples, obtained from upstream sites of the Han River and from its tributaries, were listed in Table 1. According to PCA results, samples were separated in different seasons (Fig. 2a), indicating that the environmental background values of rivers in two seasons had obvious difference, but the difference between rivers was not obvious. In the PCA results, the two extracted components accounted for $58.8 \%$ of the total variance.

\subsection{Bacterioplankton diversity}

A total of 610816 high quality reads and 14105 operational taxonomic units (OTUs) were collected by analyzing these 64 samples. The rarefaction curves illustrated that the OTUs recovered by the current sequencing depth were sufficient to represent the bacterioplankton communities (Fig. $2 \mathrm{~b}$ ). In addition, the Good's coverage in each sample was ranged from 96.96 to $99.99 \%$, indicating the characteristic representation of microbial communities by the current bacterial profiles (Table 2). The total number of OTUs in November was 8,515, much higher than the 4,402 in April. And the OTUs shared by the two seasons accounted for $17.5 \%$ of all sample OTUs (Fig. 2c).

According to the Mann-Whitney $U$ tests, the Pielou's evenness in April notably exceeded that in November $(p=0.001)(T a b l e ~ 2)$. In contrast, there is no significant difference on the Shannon index $(p=0.2)$ and the Chao1 richness index $(p=0.07)$. On the other hand, the Shannon index and Pielou's evenness increased slightly from headwaters towards river mouths in the upper reaches of the Han River, but Shannon index fluctuated widely among its tributaries.

\subsection{Bacterial community at the phylum and genus level}

The percentage of reads within different taxonomic groups are shown in Fig. 3. The most abundant genera were Comamonadaceae_unclassified (22.6\%), Flavobacterium (13.4\%), Planktophila (4.6\%) and Siphonobacter (3.8\%). The relative abundance of Actinobacteria increased significantly with the increase of river length in the mainstem of the Han River $(r=0.96, p<0.01)$, while that of Bacteroidetes decreased slightly based on Pearson correlation analysis $(r=-0.65, p=0.11)$ (Fig. 4).

SourceTracker analysis based on the OTU table revealed that proportion of the microbial community in the mainstream came from its tributaries. Five tributaries were found to be importance sources of taxa to the Han River, however in both months a large proportion of 0TUs (37.84\% and $36.34 \%$, respectively) had unknown sources (Fig. 5a, c). At the same time, Fig. 5 (b, d) shows that the proportion of OTUs of unknown origin generally increased in downstream stations.

\subsection{Influence of environmental parameters on the bacterioplankton community}

RDA was employed to analyze the correlation between OTU relative abundance and driving parameters $(p \leq 0.050)$ (Fig. 6). Among the main factors (Table 3), $\mathrm{pH}(\mathrm{p}=0.001), \mathrm{TN}(\mathrm{p}=0.001)$, Cond $(\mathrm{p}=0.001), \mathrm{NH}_{4}{ }^{+}-\mathrm{N}(\mathrm{p}=0.002), \mathrm{DO}(\mathrm{p}=0.002), \mathrm{NO}_{2}{ }^{-}-\mathrm{N}(\mathrm{p}=0.003), \mathrm{Chl}-\mathrm{a}(\mathrm{p}=0.027)$ and T $(\mathrm{p}$ $=0.039$ ) exhibited significant impact on the bacterioplankton community. Bioenv analysis in Table 4 showed that $\mathrm{pH}$ was the optimal singleparameter to explain the variance of OTU relative abundance (Bioenv correlation= 0.4629 ).

\section{Discussion And Conclusions}

It is reported that Proteobacteria, Bacteroidetes and Actinobacteria are three of the most abundant phyla in rivers (Wang et al. 2017, Liu et al. 2018). However, the relative abundance of Actinobacteria increased gradually from headwaters to lower reaches, while that of Bacteroidetes decreased gradually in the present study. However, there was no similar pattern of Actinobacteria abundance in the tributaries. At the same time, the rapidly growing Bacteroidetes based on the r-strategist lifestyles, utilized available resources in the 'new' environment of upper reaches of the river (Newton et al. 2011, Read et al. 2015). However, competition may become more intense in lower reaches, favoring species that were more competitive and had lower growth rates (Read et al. 2015). For example, the growth rate of Freshwater Actinobacteria was reported to be slower than other phyla 
(Šimek et al. 2006). Furthermore, the size of Actinobacteria was small, increasing the difficulty for them to graze (Wang et al. 2019). All these factors were beneficial to relative abundance of Actinobacteria increased with the increase of river length. Water residence time was correlated with the length of the river network, in general, it took more time for surface water to travel throughout longer networks (Stewart et al. 2009). We speculated that this was why community succession occurred in the mainstream rather than in the tributaries.

Our results indicated that the diversity in the Han River increased slightly towards river mouths, with the lowest diversity observed from headwaters, which was consistent with Read et al. (2015). As a river flowed downstream, the bacterial communities were better adjusted to the 'natives' environment, further to develop and outcompete the transient 'vagabond' or 'tourist' species (Newton et al. 2011, Crump et al. 2012). This conclusion was confirmed by the slightly increased Pielou's evenness from headwaters towards river mouths, as well as the succession in bacterial composition of the planktonic community. However, this result was different from that reported by Savio et al. (2015), which was ascribed to the spatial scale of research activities. For example, a small-spatial scale (spanning from $2^{\circ} 8^{\prime} \mathrm{W}$ to $43^{\prime} \mathrm{E}$ ) of taxa was studied by Read et al. (2015), whereas Savio's study focused on a large-scale analysis (ranging from 10 to $30^{\circ} \mathrm{E}$ ). Along the 2,600-kilometer Danube River, which was bordered by many large cities, the disturbance to the bacterioplankton community had been greatly intensified. Our result was also inconsistent with previous studies of lakes proposing that bacterioplankton richness decreased with the direction of water flow (Ruiz-Gonzalez et al. 2015, Logue et al. 2012). The reason may be that bacterioplankton richness in the lake was affected by the nutrient availability (Cardinale et al. 2009), lake chain number (Kratz et al. 1997), lake area and catchment area (MacArthur \& Wilson, 1967). For example, Kratz et al. (1997) hypothesized that lake's landscape location can determine the hydrology, geomorphology and biological characteristics of the lake, which may have an impact on bacterioplankton richness. Therefore, with shifts of hydrological channels, geomorphology and biological characteristics, bacterioplankton richness may change in dependence of lake chain number (Logue et al. 2012).

SourceTracker, a Bayesian approach has been applied to predict the source proportions (Knights et al. 2011), to identify microbial source of cesarean-born infants (Dominguez-Bello et al. 2016), and to evaluate water source contributions of microbial contamination (Henry et al. 2016). In our study, the tributaries were demonstrated to be the original microbial part of the main stream. The proportion of OTUs of unknown origin (according to the SourceTracker analysis) generally increased in the main stream from headwaters to lower reaches. The reason may be the increase of downstream tributaries and the enhancement of human activities (Li et al. 2009). First, as the number of tributaries from downstream into the mainstream increases, the bacteria from the tributaries will accumulate in the mainstream. And we only studied five of the many tributaries, and there were still many tributaries that had not been studied (Finn et al. 2011). Second, previous studies showed that human disturbance and farmland activities in the downstream were increasing, which would lead to the import of foreign bacteria (Li et al. 2009). Genera-Acinetobacter appeared in the downstream of the mainstream, and this kind of bacteria is generally more in urban wastewater (Newton et al. 2013). As a result, the proportion of unknown bacteria was accordingly increased.

The previous studies indicated that the surrounding conditions and available nutrient sources exhibited direct impact on the composition and biodiversity of microbial community in the river (Huang et al. 2011, Cole et al. 2012). RDA and Bioenv analysis showed that environmental parameters were correlated with the changes in the bacterioplankton community. pH can directly affect the growth of microorganisms and affect the community structure and diversity of microorganisms by changing the physical and chemical properties of water (Yannarell et al. 2005, Langenheder et al. 2006). Chl-a was a good indicator of the stock of phytoplankton (Bai et al. 2009), and studies found that planktonic bacteria were closely related to the community structure of phytoplankton (Kirchman et al. 1991, Teeling et al. 2012). Bacteria not only absorb the organic matter produced by phytoplankton but also provide organic nutrients and growth factors for phytoplankton. They may be mutually beneficial and symbiotic relationship (Zhu et al. 2018). Previous studies in freshwater environments found that nitrogen nutrients and phosphorus were key factors affecting the composition of microorganisms (Liu et al. 2012); however, our study demonstrated that phosphorus had little effect on the composition of microorganisms. This difference may be due to the use of phosphorus-containing detergents and chemical fertilizers, resulting in higher phosphorus concentrations, and nitrogen nutrients became a limiting factor affecting the distribution of microorganisms (Lü et al. 2011).

As the main source of water for the Middle Route of China's South-to-North Water Diversion Project, the upper reaches of the Han River are the water supply area of the Danjiangkou Reservoir. Hence, it is necessary to strengthen the monitoring of water quality in near cities, as well as to strictly control the inflow of domestic sewage and industrial wastewater. At the same time, rivers also require the strengthening of control over activities such as dredging. Some rivers are disturbed by activities such as dredging and agricultural production, which destroy the original habitat conditions and cause fluctuations in species diversity. The study also found that the river length affected the growth and survival of certain planktonic bacteria. Therefore, ecological assessment should be performed before building a dam to reduce the impact of the dam on the environment. The diversity and spatial distribution have been highlighted to evaluate the bacterioplankton communities in the main tributaries of the Han River. On the other hand, there results in this study provide an insightful reference to understand the bacterioplankton diversity, to clarify the environmental factors affecting the distribution of bacterioplankton diversity in the region, and to provide data support for further improvement of the water quality in the region. In addition, a large number of bacterioplankton have not been identified, and subsequent development of functional bacterioplankton resources in the region can be enhanced by combining new technologies such as metagenomics.

\section{Declarations}

Acknowledgements 
We thank Yiming Hou and Haiqiang Yang for helping with the experiment.

\section{Authors' contributions}

All authors contributed to the study conception and design. He Sun: Investigation, Writing - original draft, Writing - review \& editing, Visualization.

Baozhu Pan: Investigation, Writing - original draft, Writing - review \& editing, Visualization. Haoran He: Investigation, Writing - review \& editing, Visualization. Gengnan Zhao: Writing - review \& editing, Supervision. Xiaoming Jiang: Investigation, Writing - review \& editing. Xu Han, Hao Wang: Conceptualization, Writing - review \& editing, Supervision, Project administration. All the authors read and approved the manuscript.

\section{Funding}

This work was financially supported by National Natural Science of China (No. 31770460, 51622901, 51709225) and the National Natural Science Foundation of Shannxi (2018JQ5121, 2019JM-153).

\section{Data availability}

Data that support the findings of this study have been deposited in the public National Center for Biotechnology Information (NCBI) with the accession codes: SRP142494.

\section{Compliance with ethical standards}

\section{Competing interests}

The authors declare that they have no competing interests

\section{Ethical approval and consent to participate}

Not applicable

\section{Consent to publish}

Not applicable

\section{References}

Adhikari NP, Liu Y, Liu K, Zhang F, Adhikari S, Chen Y, Liu X (2019) Bacterial community composition and diversity in Koshi River, the largest river of Nepal. Ecol Indic 104: 501-511

https://doi.org/10.1016/j.ecolind.2019.05.009

Bai J, Shi Y, Song L, Li Z (2009) Distribution Character of Bacterioplankton Biomass and Their Relationship with Environmental Factors in the Northwest of the Yellow Sea. Periodical of Ocean University of China 39: 592-596

Bouvy M, Bettarel Y, Bouvier C, Domaizon I and others (2011) Trophic interactions between viruses, bacteria and nanoflagellates under various nutrient conditions and simulated climate change. Environ Microbiol 13: 1842-1857

https://doi.org/10.1111/j.1462-2920.2011.02498.x

Bray JR, Curtis JT (1957) An Ordination of the Upland Forest Communities of Southern Wisconsin. Ecol Monogr 27: $325-349$

Cao Y, Tan X, He W, Geng Z, Liu S, She D, Hou L (2016) The metabolism characteristics of microbial community in different forest soil in Qinling Mountains Area. Acta Ecologica Sinica 36: 2978-2986

Caporaso JG, Kuczynski J, Stombaugh J, Bittinger K, Bushman FD, Costello EK and others (2010) QIIME allows analysis of high-throughput community sequencing data. Nat Methods 7: 335-336

https://doi.org/10.1038/nmeth.f.303

Cardinale BJ, Hillebrand H, Harpole WS, Gross K, Ptacnik R (2009) Separating the influence of resource 'availability' from resource 'imbalance' on productivity-diversity relationships. Ecol Lett 12: 475-487

https://doi.org/10.1111/j.1461-0248.2009.01317.x 
Chen Q (2017) The Study of Enitrifying Bacteria Community in River Sediments of Jinshui River Watershed in the Upper Han River. The Wuhan Botanical Garden of the Chinese Academy of Sciences

Chen W, Ren K, Isabwe A, Chen H, Liu M, Yang J (2019) Stochastic processes shape microeukaryotic community assembly in a subtropical river across wet and dry seasons. Microbiome 7: 1-16

https://doi.org/10.1186/s40168-019-0749-8

Chen Z, Ding C, Zhu J, Li B (2017) Community structure and influencing factors of bacterioplankton during low water periods in Danjiangkou Reservoir. China Environ Sci 37: 336-344

Cole JK, Peacock JP, Dodsworth JA, Williams AJ and others (2013) Sediment microbial communities in Great Boiling Spring are controlled by temperature and distinct from water communities. ISME J 7: 718-729

https://doi.org/10.1038/ismej.2012.157

Crump BC, Amaral-Zettler LA, Kling GW (2012) Microbial diversity in arctic freshwaters is structured by inoculation of microbes from soils. ISME J 6: 1629

https://doi.org/10.1038/ismej.2012.9

Crump BC, Peterson BJ, Raymond PA, RMW A, Rinehart A and others (2009) Circumpolar synchrony in big river bacterioplankton. Proc Natl Acad Sci USA 106: $21208-21212$

https://doi.org/10.1073/pnas.0906149106

Dominguez-Bello MG, De JKM, Nan S and others (2016) Partial restoration of the microbiota of cesarean-born infants via vaginal microbial transfer. Nature Medicine 22: 250-253

https://doi.org/10.1038/nm.4039

Findlay S (2010) Stream microbial ecology. J N Am Benthol Soc 29: 170-181

Finn DS, Bonada N, Múrria C, Hughes JM (2011) Small but mighty: headwaters are vital to stream network biodiversity at two levels of organization. J. North Am. Benthol. Soc. 30: 963-980

https://doi.org/10.1899/11-012.1

Henry R, Schang C, Coutts S and others (2016) Into the deep: evaluation of SourceTracker for assessment of faecal contamination of coastal waters. Water research 93: 242-253

https://doi.org/10.1016/j.watres.2016.02.029

Hu A, Yang X, Chen N, Hou L, Ma Y, Yu C-P (2014) Response of bacterial communities to environmental changes in a mesoscale subtropical watershed, Southeast China. Sci Total Environ 472: 746-756

https://doi.org/10.1016/j.scitotenv.2013.11.097

Huang S, Chen C, Wu Y, Wu Q, Zhang R (2011) Characterization of depth-related bacterial communities and their relationships with the environmental factors in the river sediments. World J Microb Biot 27: 2655-2664

https://doi.org/10.1007/s11274-011-0739-x

Jani K, Ghattargi V, Pawar S, Inamdar M, Shouche Y, Sharma A (2018) Anthropogenic Activities Induce Depletion in Microbial Communities at Urban Sites of the River Ganges. Curr Microbiol 75: 79-83

https://doi.org/10.1007/s00284-017-1352-5

Kirchman DL, Suzuki Y, Garside C, Ducklow HW (1991) High turnover rates of dissolved organic carbon during a spring phytoplankton bloom. Nature 352: 612-614

https://doi.org/10.1038/352612a0 
Knights D, Kuczynski J, Charlson ES and others (2011) Bayesian community-wide culture-independent microbial source tracking. Nat methods 8: 761

https://doi.org/10.1038/nmeth.1650

Kratz TK, Webster KE, Bowser CJ, Magnuson JJ, Benson BJ (1997) The influence of landscape position on lakes in northern Wisconsin. Freshwater Biol 37: 209-217

https://doi.org/10.1046/j.1365-2427.1997.00149.x

Langenheder S, Lindstrom ES, Tranvik LJ (2006) Structure and function of bacterial communities emerging from different sources under identical conditions. Appl Environ Microbiol 72: 212-220

https://doi.org/10.1128/AEM.72.1.212-220.2006

Li S, Gu S, Tan X, Zhang Q (2009) Water quality in the upper Han River basin, China: The impacts of land use/land cover in riparian buffer zone. J. Hazard. Mater 165: 317-324

https://doi.org/10.1016/j.jhazmat.2008.09.123

Li Y, Gao Y, Zhang W, Wang C and others (2019) Homogeneous selection dominates the microbial community assembly in the sediment of the Three Gorges Reservoir. Sci Total Environ 690: 50-60

https://doi.org/10.1016/j.scitotenv.2019.07.014

Liu T, Zhang AN, Wang J, Liu S and others (2018) Integrated biogeography of planktonic and sedimentary bacterial communities in the Yangtze River. Microbiome 6: 16

https://doi.org/10.1186/s40168-017-0388-x

Liu Z (2014) Structure and annual variation of phytoplankton community at upstream of Hanjiang River. Journal of Northwest A \& F University (Natural Science Edition) 42: 176-182

https://doi.org/10.13207/j.cnki.jnwafu.2014.07.019

Liu Z (2016) The present situation of water quality in the upper reaches of the han river and its treatment and strengthening path. Water Resources Development Research 16: 75-77

Liu Z, Huang S, Sun G, Xu Z, Xu M (2012) Phylogenetic diversity, composition and distribution of bacterioplankton community in the Dongjiang River, China. FEMS Microbiol Ecol 80: 30-44

https://doi.org/10.1111/j.1574-6941.2011.01268.x

Llirós M, Inceoğlu Ö, García-Armisen T, Anzil A and others (2014) Bacterial Community Composition in Three Freshwater Reservoirs of Different Alkalinity and Trophic Status. PLoS ONE 9: e116145

https://doi.org/10.1371/journal.pone.0116145

Logue JB, Langenheder S, Andersson AF, Bertilsson S, Drakare S, Lanzen A, and Lindstrom ES (2012) Freshwater bacterioplankton richness in oligotrophic lakes depends on nutrient availability rather than on species-area relationships. ISME J 6: 1127-1136

https://doi.org/10.1038/ismej.2011.184

Louca S, Parfrey LW, Doebeli M (2016) Decoupling function and taxonomy in the global ocean microbiome. Science 353: $1272-1277$

https://doi.org/10.1126/science.aaf4507

Lü MLv M, Wang J, Fan Z, Huang Y (2011) The spatial variations of bacterioplankton community composition in Lake Dianchi and their relation to environmental factors. Environment Science 31: 299-306

https://doi.org/10.13671/j.hjkxxb.2011.02.012

MacArthur RH, Wilson EO (1967) The theory of island biogeography. Princeton University Press: Princeton, New Jersey 
McCaulou D, Bales R, Arnold R (1995) Effect of Temperature-Controlled Motility on Transport of Bacteria and Microspheres Through Saturated Sediment. Water Resources Res 31: 271-280

https://doi.org/10.1029/94WR02569

McDonald D, Price MN, Goodrich J, Nawrocki EP, DeSantis TZ, Probst A and others (2012) An improved Greengenes taxonomy with explicit ranks for ecological and evolutionary analyses of bacteria and archaea. ISME J 6: 610-618

https://doi.org/10.1038/ismej.2011.139

Mo Y, Zhang W, Yang J, Lin Y, Yu Z, \& Lin S (2018) Biogeographic patterns of abundant and rare bacterioplankton in three subtropical bays resulting from selective and neutral processes. ISME J 12: 2198-2210

https://doi.org/10.1038/s41396-018-0153-6

Nakano S, Ishii N, Manage PM, Kawabata Z (1998) Trophic roles of heterotrophic nanoflagellates and ciliates among planktonic organisms in a hypereutrophic pond. Aquat Microb Ecol 16: 153-161

https://doi.org/10.3354/ame016153

Newton RJ, Jones SE, Eiler A, McMahon KD, Bertilsson S (2011) A guide to the natural history of freshwater lake bacteria. Microbiol Mol Biol Rev 75: $14-49$

https://doi.org/10.1128/MMBR.00028-10

Newton, R.J., Bootsma, M.J., Morrison, H.G., Sogin, M.L., Mclellan, S.L., 2013. A microbial signature approach to identify fecal pollution in the waters off an urbanized coast of lake Michigan. Microb. Ecol. 65 (4), 1011-1023.

Pérez MT, Sommaruga R (2006) Differential effect of algal- and soil-derived dissolved organic matter on alpine lake bacterial community composition and activity. Limnol Oceanogr 51: 2527-2537

https://doi.org/10.4319/lo.2006.51.6.2527

Read DS, Gweon HS, Bowes MJ, Newbold LK, Field D, Bailey MJ, Griffiths RI (2015) Catchment-scale biogeography of riverine bacterioplankton. ISME J 9: 516-526

https://doi.org/10.1038/ismej.2014.166

Ruiz-González C, Niño-García JP, Giorgio PA (2015) Terrestrial origin of bacterial communities in complex boreal freshwater networks. Ecol Lett 18: 1198-1206

https://doi.org/10.1111/ele.12499

Savio D, Sinclair L, ljaz UZ, Parajka J and others (2015) Bacterial diversity along a 2600 km river continuum. Environ Microbiol 17: 4994-5007

https://doi.org/10.1111/1462-2920.12886

Schultz GE Jr GE, Kovatch JJ, Anneken EM (2013) Bacterial diversity in a large, temperate, heavily modified river, as determined by pyrosequencing. Aquat Microb Ecol 70: 169-179

https://doi.org/10.3354/ame01646

Sieburth JM (1967) Seasonal selection of estuarine bacteria by water temperature. J Exp Mar Biol Ecol 1: 98-121

https://doi.org/10.1016/0022-0981(67)90009-3

Shan J, Ji R, Yu Y, Xie Z, Yan X (2015) Biochar, activated carbon, and carbon nanotubes have different effects on fate of 14C-catechol and microbial community in soil. Sci Rep 5: 16000

https://doi.org/10.1038/srep16000

Šimek K, Horňák K, Jezbera J and others (2006) Maximum growth rates and possible life strategies of different bacterioplankton groups in relation to phosphorus availability in a freshwater reservoir. Environ Microbio I8: 1613-1 624

https://doi.org/10.1038/srep16000

Page 9/18 
Sorokin DY, Berben T, Melton ED, Overmars L, Vavourakis CD, Muyzer G (2014) Microbial diversity and biogeochemical cycling in soda lakes. Extremophiles 18: 791-809

https://doi.org/10.1007/s00792-014-0670-9

Staley C, Gould TJ, Wang P, Phillips J and others (2014) Bacterial community structure is indicative of chemical inputs in the Upper Mississippi River. Front. Microbiol. 5: 524

https://doi.org/10.3389/fmicb.2014.00524

Stewart RJ, Wollheim WM, Gooseff MN and others (2009) Separation of River Network-Scale Nitrogen Removal among the Main Channel and Two Transient Storage Compartments. Water Resources Res 47: 178-191

https://doi.org/10.1029/2010WR009896

Tamames J, Abellán JJ, Pignatelli M, Camacho A, Moya A (2010) Environmental distribution of prokaryotic taxa. BMC Microbiol 10: 85 https://doi.org/https://doi.org/10.1186/1471-2180-10-85

Teeling H, Fuchs BM, Becher D, Klockow C and others (2012) Substrate-Controlled Succession of Marine Bacterioplankton Populations Induced by a Phytoplankton Bloom. Science 336: 608-611

https://doi.org/10.1126/science.1218344

Wang J, Li H, Zhang K, Gao L, Wan Y (2019) Isolation and metabolites of myxobacteria from the Danjiang River in Qinling Mountains. Journal of Northwest A \& F University (Natural Science Edition) 47: 63-79

https://doi.org/10.13207/j.cnki.jnwafu.2019.10.008

Wang P, Wang X, Wang C, Miao L, Hou J, Yuan Q (2017) Shift in bacterioplankton diversity and structure: Influence of anthropogenic disturbances along the Yarlung Tsangpo River on the Tibetan Plateau, China. Sci Rep 7: 12529

https://doi.org/10.1038/s41598-017-12893-4

Wang P, Zhao J, Xiao H, Yang W, Yu X (2019) Bacterial community composition shaped by water chemistry and geographic distance in an anthropogenically disturbed river. Sci Total Environ 655: 61-69

https://doi.org/10.1016/j.scitotenv.2018.11.234

Wang Q, Garrity GM, Tiedje JM, Cole JR (2007) Naive Bayesian classifier for rapid assignment of rRNA sequences into the new bacterial taxonomy. Appl Env Microbiol 73: 5261-5267

https://doi.org/10.1128/AEM.00062-07

Wang X, Tan X (2017) Macroinvertebrate community in relation to water quality and riparian land use in a substropical mountain stream, China. Environmental Science and Pollution Research 24: 14682-14689

https://doi.org/10.1007/s11356-017-9042-1

Wu Y, Wang Y, Hu M, Hu D (2015) Ecological distribution and its influencing factors of bacterioplankton in the typical tributaries of Three Gorges Reservo. Chinese Journal of Ecology 34: 1060-1065

https://doi.org/10.13292/j.1000-4890.20150304.019

Yannarell AC, Triplett EW (2005) Geographic and environmental sources of variation in lake bacterial community composition. Appl Environ Microbiol 71: 227-239

https://doi.org/10.1128/AEM.71.1.227-239.2005

Zhao, G., Pan B., Li Y., Zheng X., Zhu P., Zhang L., He H., 2020. Phytoplankton in the heavy sediment-laden Weihe River and its tributaries from the northern foot of the Qinling Mountains: community structure and environmental drivers. Environ Sci Pollut R 27:8359-8370.

https://doi.org/10.1007/s11356-019-07346-6 
Zhu JM, Hong YG, Zada S, Hu Z, Wang H (2018) Spatial Variability and Co-acclimation of Phytoplankton and Bacterioplankton Communities in the Pearl River Estuary,China. Frontiers in Microbiology 9: 2503

https://doi.org/10.3389/fmicb.2018.02503

\section{Tables}

Table. 1 Water environmental parameters (mean \pm standard deviation) of the survey sample in mainstem and tributaries of the Han River

Notes: temperature=T; conductivity=Cond; dissolved oxygen=DO; turbidity=Turd; total nitrogen=TN; ammonia nitrogen= $\mathrm{NH}_{4}{ }^{+}-\mathrm{N} ;$ nitrate nitrogen= $\mathrm{NO}_{3}{ }^{-}-\mathrm{N}$; nitrite nitrogen $=\mathrm{NO}_{2}{ }^{-}-\mathrm{N}$; total phosphorus=TP; and chlorophyll $a=\mathrm{Chl} a$.

\begin{tabular}{|c|c|c|c|c|c|c|c|c|c|c|c|c|}
\hline \multirow[t]{2}{*}{$\begin{array}{l}\text { Sampling } \\
\text { time }\end{array}$} & \multirow[t]{2}{*}{ Rivers } & $\mathbf{T}$ & $\mathrm{pH}$ & Cond & DO & Turd & $\mathrm{TN}$ & $\begin{array}{l}\mathrm{NH}_{4}^{+}- \\
\mathrm{N}\end{array}$ & $\begin{array}{l}\mathrm{NO}_{3}^{-}= \\
\mathrm{N}\end{array}$ & $\mathrm{NO}_{2}^{-}-\mathrm{N}$ & TP & $\mathrm{Chl} a$ \\
\hline & & ${ }^{\circ} \mathrm{C}$ & & uS cm-1 & $\mathrm{mg} \mathrm{L}^{-1}$ & NTU & $\mathrm{mg} \mathrm{L}_{1}^{-}$ & $\mathrm{mg} \mathrm{L}_{1}^{-}$ & $\mathrm{mg} \mathrm{L}_{1}^{-}$ & $\mathrm{mg} \mathrm{L}^{-1}$ & $\mathrm{mg} \mathrm{L}^{-1}$ & $\mathrm{mg} \mathrm{m}^{-3}$ \\
\hline \multirow{12}{*}{$\begin{array}{l}\text { In } \\
\text { November } \\
2017\end{array}$} & \multirow{2}{*}{$\begin{array}{l}\text { Upper } \\
\text { reaches } \\
\text { of the } \\
\text { Han } \\
\text { River }\end{array}$} & $14.56 \pm$ & $8.37 \pm$ & $382 \pm 112$ & $9.56 \pm$ & $31.28 \pm$ & $3.53 \pm$ & $0.53 \pm$ & $2.45 \pm$ & $0.03 \pm$ & $0.050 \pm$ & $1.75 \pm$ \\
\hline & & 1.51 & 0.14 & & 0.79 & 15.12 & 0.23 & 0.14 & 0.19 & 0.02 & 0.015 & 1.16 \\
\hline & \multirow{2}{*}{$\begin{array}{l}\text { Xushui } \\
\text { River }\end{array}$} & $12.75 \pm$ & $8.49 \pm$ & $192 \pm 54$ & $10.37 \pm$ & $2.75 \pm$ & $1.65 \pm$ & $0.49 \pm$ & $1.12 \pm$ & $0.03 \pm$ & $0.048 \pm$ & $3.39 \pm$ \\
\hline & & 0.61 & 0.17 & & 0.25 & 1.10 & 0.75 & 0.01 & 0.74 & 0.01 & 0.007 & 1.63 \\
\hline & \multirow{2}{*}{$\begin{array}{l}\text { Jinshui } \\
\text { River }\end{array}$} & $11.02 \pm$ & $8.57 \pm$ & $187 \pm 88$ & $10.58 \pm$ & $2.77 \pm$ & $0.98 \pm$ & $0.49 \pm$ & $0.47 \pm$ & $0.02 \pm$ & $0.036 \pm$ & $1.48 \pm$ \\
\hline & & 1.35 & 0.03 & & 0.19 & 2.49 & 0.19 & 0.02 & 0.18 & 0.01 & 0.004 & 1.09 \\
\hline & \multirow{2}{*}{$\begin{array}{l}\text { Yue } \\
\text { River }\end{array}$} & $15.36 \pm$ & $8.39 \pm$ & $384 \pm 33$ & $9.83 \pm$ & $33.90 \pm$ & $1.97 \pm$ & $0.50 \pm$ & $1.33 \pm$ & $0.03 \pm$ & $0.083 \pm$ & $4.09 \pm$ \\
\hline & & 1.17 & 0.18 & & 0.48 & 32.20 & 0.10 & 0.01 & 0.09 & 0.02 & 0.011 & 1.57 \\
\hline & \multirow{2}{*}{$\begin{array}{l}\text { Xun } \\
\text { River }\end{array}$} & $14.06 \pm$ & $8.63 \pm$ & $356 \pm 140$ & $9.82 \pm$ & $8.21 \pm$ & $1.92 \pm$ & $0.33 \pm$ & $1.45 \pm$ & $0.02 \pm$ & $0.055 \pm$ & $2.67 \pm$ \\
\hline & & 2.65 & 0.14 & & 0.42 & 3.83 & 0.26 & 0.19 & 0.25 & 0.01 & 0.005 & 1.22 \\
\hline & \multirow{2}{*}{$\begin{array}{l}\text { Jinqian } \\
\text { River }\end{array}$} & $14.69 \pm$ & $8.76 \pm$ & $347 \pm 58$ & $9.62 \pm$ & $7.88 \pm$ & $1.96 \pm$ & $0.39 \pm$ & $1.42 \pm$ & $0.02 \pm$ & $0.050 \pm$ & $3.86 \pm$ \\
\hline & & 1.58 & 0.29 & & 0.56 & 6.93 & 0.34 & 0.18 & 0.31 & 0.01 & 0.006 & 2.71 \\
\hline \multirow{12}{*}{$\begin{array}{l}\text { In April } \\
2018\end{array}$} & \multirow{2}{*}{$\begin{array}{l}\text { Upper } \\
\text { reaches } \\
\text { of the } \\
\text { Han } \\
\text { River }\end{array}$} & $15.40 \pm$ & $7.38 \pm$ & $221 \pm 22$ & $8.58 \pm$ & $37.29 \pm$ & $2.17 \pm$ & $0.70 \pm$ & $1.10 \pm$ & $0.11 \pm$ & $0.071 \pm$ & $3.08 \pm$ \\
\hline & & 2.30 & 0.14 & & 0.62 & 16.88 & 0.30 & 0.16 & 0.48 & 0.09 & 0.008 & 1.45 \\
\hline & \multirow{2}{*}{$\begin{array}{l}\text { Xushui } \\
\text { River }\end{array}$} & $12.52 \pm$ & $7.49 \pm$ & $137 \pm 38$ & $9.23 \pm$ & $23.93 \pm$ & $1.99 \pm$ & $0.58 \pm$ & $1.39 \pm$ & $0.05 \pm$ & $0.068 \pm$ & $2.46 \pm$ \\
\hline & & 0.84 & 0.17 & & 0.42 & 9.95 & 0.27 & 0.15 & 0.61 & 0.04 & 0.005 & 0.41 \\
\hline & \multirow{2}{*}{$\begin{array}{l}\text { Jinshui } \\
\text { River }\end{array}$} & $15.32 \pm$ & $7.56 \pm$ & $145 \pm 64$ & $9.82 \pm$ & $7.80 \pm$ & $1.79 \pm$ & $0.76 \pm$ & $0.70 \pm$ & $0.05 \pm$ & $0.042 \pm$ & $1.45 \pm$ \\
\hline & & 3.50 & 0.03 & & 1.04 & 5.86 & 0.28 & 0.23 & 0.36 & 0.03 & 0.008 & 0.33 \\
\hline & \multirow{2}{*}{$\begin{array}{l}\text { Yue } \\
\text { River }\end{array}$} & $22.36 \pm$ & $7.40 \pm$ & $198 \pm 29$ & $8.78 \pm$ & $85.46 \pm$ & $2.49 \pm$ & $1.44 \pm$ & $0.84 \pm$ & $0.06 \pm$ & $0.086 \pm$ & $2.37 \pm$ \\
\hline & & 2.49 & 0.18 & & 1.09 & 64.83 & 0.43 & 0.08 & 0.37 & 0.05 & 0.014 & 0.72 \\
\hline & \multirow{2}{*}{$\begin{array}{l}\text { Xun } \\
\text { River }\end{array}$} & $17.84 \pm$ & $7.66 \pm$ & $196 \pm 67$ & $9.21 \pm$ & $20.60 \pm$ & $1.91 \pm$ & $0.95 \pm$ & $0.58 \pm$ & $0.09 \pm$ & $0.055 \pm$ & $3.76 \pm$ \\
\hline & & 2.96 & 0.11 & & 0.46 & 7.91 & 0.28 & 0.31 & 0.28 & 0.06 & 0.004 & 1.65 \\
\hline & \multirow{2}{*}{$\begin{array}{l}\text { Jinqian } \\
\text { River }\end{array}$} & $21.02 \pm$ & $7.78 \pm$ & $260 \pm 45$ & $8.30 \pm$ & $19.80 \pm$ & $2.29 \pm$ & $0.58 \pm$ & $0.68 \pm$ & $0.14 \pm$ & $0.062 \pm$ & $3.31 \pm$ \\
\hline & & 2.89 & 0.27 & & 0.31 & 5.40 & 0.22 & 0.12 & 0.22 & 0.10 & 0.008 & 1.27 \\
\hline
\end{tabular}

Table 2 Summary of alpha diversity indices, including Chao10ShannonロPielou and Good's coverage 


\begin{tabular}{|c|c|c|c|c|c|c|}
\hline Sample ID & Month & No. of OTU & Chao1 & Shannon & Pielou & Good's coverage \\
\hline HJ1 & November & 634 & 676 & 7.01 & 0.75 & $99.08 \%$ \\
\hline $\mathrm{HJ} 2$ & November & 691 & 716 & 8.13 & 0.86 & $99.44 \%$ \\
\hline HJ3 & November & 1230 & 1420 & 8.45 & 0.81 & $96.96 \%$ \\
\hline HJ4 & November & 843 & 891 & 8.16 & 0.83 & $98.93 \%$ \\
\hline HJ5 & November & 1150 & 1205 & 9.33 & 0.92 & $98.71 \%$ \\
\hline HJ6 & November & 648 & 653 & 8.27 & 0.89 & $99.77 \%$ \\
\hline HJ7 & November & 869 & 937 & 8.37 & 0.85 & $98.71 \%$ \\
\hline XS1 & November & 340 & 341 & 7.33 & 0.87 & $99.94 \%$ \\
\hline XS2 & November & 448 & 458 & 7.32 & 0.83 & $99.71 \%$ \\
\hline XS3 & November & 401 & 406 & 7.31 & 0.84 & $99.84 \%$ \\
\hline XS4 & November & 426 & 450 & 6.29 & 0.70 & $99.39 \%$ \\
\hline XS5 & November & 373 & 390 & 6.48 & 0.76 & $99.68 \%$ \\
\hline JS1 & November & 1199 & 1348 & 8.06 & 0.78 & $97.37 \%$ \\
\hline JS2 & November & 1225 & 1324 & 9.13 & 0.89 & $97.96 \%$ \\
\hline JS3 & November & 1252 & 1305 & 9.64 & 0.94 & $98.68 \%$ \\
\hline JS4 & November & 319 & 319 & 7.46 & 0.90 & $99.99 \%$ \\
\hline JS5 & November & 418 & 426 & 7.01 & 0.81 & $99.74 \%$ \\
\hline Y1 & November & 190 & 190 & 6.61 & 0.87 & $99.99 \%$ \\
\hline Y2 & November & 496 & 525 & 6.43 & 0.71 & $99.33 \%$ \\
\hline Y3 & November & 544 & 552 & 7.88 & 0.86 & $99.72 \%$ \\
\hline Y4 & November & 582 & 602 & 7.50 & 0.81 & $99.56 \%$ \\
\hline Y5 & November & 638 & 743 & 6.76 & 0.70 & $98.31 \%$ \\
\hline $\mathrm{X} 1$ & November & 477 & 479 & 8.17 & 0.92 & $99.91 \%$ \\
\hline $\mathrm{X} 2$ & November & 524 & 537 & 7.86 & 0.87 & $99.75 \%$ \\
\hline $\mathrm{X} 3$ & November & 255 & 256 & 6.68 & 0.83 & $99.94 \%$ \\
\hline$X 4$ & November & 459 & 474 & 6.98 & 0.78 & $99.63 \%$ \\
\hline$\times 5$ & November & 495 & 510 & 7.49 & 0.83 & $99.62 \%$ \\
\hline JQ1 & November & 935 & 990 & 8.94 & 0.90 & $98.89 \%$ \\
\hline JQ2 & November & 546 & 555 & 7.91 & 0.87 & $99.69 \%$ \\
\hline JQ3 & November & 800 & 881 & 7.41 & 0.76 & $98.60 \%$ \\
\hline JQ4 & November & 459 & 486 & 6.28 & 0.70 & $99.48 \%$ \\
\hline JQ5 & November & 1094 & 1186 & 8.74 & 0.86 & $98.21 \%$ \\
\hline HJ1 & April & 530 & 538 & 7.24 & 0.80 & $99.69 \%$ \\
\hline HJ2 & April & 687 & 706 & 8.70 & 0.92 & $99.63 \%$ \\
\hline HJ3 & April & 647 & 669 & 8.16 & 0.87 & $99.47 \%$ \\
\hline HJ4 & April & 722 & 728 & 8.73 & 0.92 & $99.75 \%$ \\
\hline HJ5 & April & 594 & 608 & 8.58 & 0.93 & $99.70 \%$ \\
\hline HJ6 & April & 583 & 597 & 8.61 & 0.94 & $99.73 \%$ \\
\hline HJ7 & April & 482 & 486 & 8.08 & 0.90 & $99.83 \%$ \\
\hline XS1 & April & 782 & 794 & 9.00 & 0.94 & $99.66 \%$ \\
\hline
\end{tabular}

Page 12/18 


\begin{tabular}{|c|c|c|c|c|c|c|}
\hline XS2 & April & 390 & 393 & 7.62 & 0.89 & $99.88 \%$ \\
\hline XS3 & April & 499 & 509 & 8.36 & 0.93 & $99.79 \%$ \\
\hline XS4 & April & 552 & 568 & 7.40 & 0.81 & $99.59 \%$ \\
\hline XS5 & April & 728 & 744 & 8.75 & 0.92 & $99.57 \%$ \\
\hline JS1 & April & 694 & 706 & 8.54 & 0.90 & $99.66 \%$ \\
\hline JS2 & April & 500 & 504 & 8.51 & 0.95 & $99.90 \%$ \\
\hline JS3 & April & 958 & 976 & 9.38 & 0.95 & $99.46 \%$ \\
\hline JS4 & April & 388 & 390 & 7.35 & 0.85 & $99.90 \%$ \\
\hline JS5 & April & 380 & 385 & 7.18 & 0.83 & $99.81 \%$ \\
\hline Y1 & April & 603 & 615 & 8.44 & 0.91 & $99.69 \%$ \\
\hline Y2 & April & 333 & 339 & 6.79 & 0.81 & $99.84 \%$ \\
\hline Y3 & April & 415 & 422 & 7.93 & 0.91 & $99.86 \%$ \\
\hline Y4 & April & 644 & 674 & 8.75 & 0.94 & $99.57 \%$ \\
\hline Y5 & April & 601 & 604 & 8.67 & 0.94 & $99.84 \%$ \\
\hline $\mathrm{X} 1$ & April & 470 & 471 & 8.27 & 0.93 & $99.94 \%$ \\
\hline $\mathrm{X} 2$ & April & 504 & 506 & 8.17 & 0.91 & $99.90 \%$ \\
\hline X3 & April & 373 & 379 & 7.23 & 0.84 & $99.80 \%$ \\
\hline X4 & April & 281 & 286 & 7.53 & 0.93 & $99.94 \%$ \\
\hline X5 & April & 341 & 343 & 7.35 & 0.87 & $99.90 \%$ \\
\hline JQ1 & April & 578 & 597 & 8.33 & 0.91 & $99.71 \%$ \\
\hline JQ2 & April & 379 & 383 & 6.40 & 0.75 & $99.85 \%$ \\
\hline JQ3 & April & 292 & 303 & 5.42 & 0.66 & $99.79 \%$ \\
\hline JQ4 & April & 311 & 318 & 6.74 & 0.81 & $99.86 \%$ \\
\hline JQ5 & April & 314 & 325 & 6.84 & 0.82 & $99.81 \%$ \\
\hline
\end{tabular}

Table 3 Effects of geographical and environmental factors on bacterial community composition

\begin{tabular}{|lll|}
\hline Variables & $\mathbf{r}^{2}$ & $\operatorname{Pr}(>\mathbf{r})$ \\
\hline $\mathrm{pH}$ & 0.2063 & 0.001 \\
$\mathrm{TN}$ & 0.1149 & 0.001 \\
\hline $\mathrm{Cond}$ & 0.1163 & 0.001 \\
\hline $\mathrm{DO}$ & 0.0956 & 0.002 \\
\hline $\mathrm{NH}_{4}{ }^{+}{ }^{-\mathrm{N}}$ & 0.0834 & 0.002 \\
\hline $\mathrm{NO}_{2}{ }^{-} \mathrm{N}$ & 0.0579 & 0.003 \\
\hline $\mathrm{Chl}-\mathrm{a}$ & 0.0294 & 0.027 \\
\hline $\mathrm{T}$ & 0.0137 & 0.039 \\
\hline
\end{tabular}

Table 4 Correlations between environmental variables and

\section{OTU relative abundance}




\begin{tabular}{|lc|}
\hline Environmental variables & Correlation \\
\hline $\mathrm{pH}$ & 0.4629 \\
\hline $\mathrm{pH}+$ Cond & 0.5654 \\
\hline $\mathrm{pH}+\mathrm{Cond}+\mathrm{DO}$ & 0.5468 \\
\hline $\mathrm{pH}+\mathrm{Cond}+\mathrm{NH}_{4}{ }^{+} \mathrm{N}+\mathrm{Tur}$ & 0.5477 \\
\hline $\mathrm{pH}+\mathrm{Cond}+\mathrm{NH}_{4}{ }^{+}-\mathrm{N}+\mathrm{Do}+\mathrm{TN}$ & 0.5502 \\
\hline $\mathrm{pH}+$ Cond $+\mathrm{NH}_{4}{ }^{+}-\mathrm{N}+\mathrm{Do}+\mathrm{TN}+\mathrm{Tur}$ & 0.5569 \\
\hline $\mathrm{pH}+$ Cond $+\mathrm{NH}_{4}{ }^{+}-\mathrm{N}+\mathrm{Do}+\mathrm{TN}+\mathrm{Tur}+\mathrm{TN}$ & 0.5444 \\
\hline $\mathrm{pH}+$ Cond $+\mathrm{NH}_{4}{ }^{+}-\mathrm{N}+\mathrm{Do}+\mathrm{TN}+\mathrm{Tur}+\mathrm{TP}+\mathrm{NO}_{3}{ }^{-}-\mathrm{N}$ & 0.5310 \\
\hline
\end{tabular}

\section{Figures}

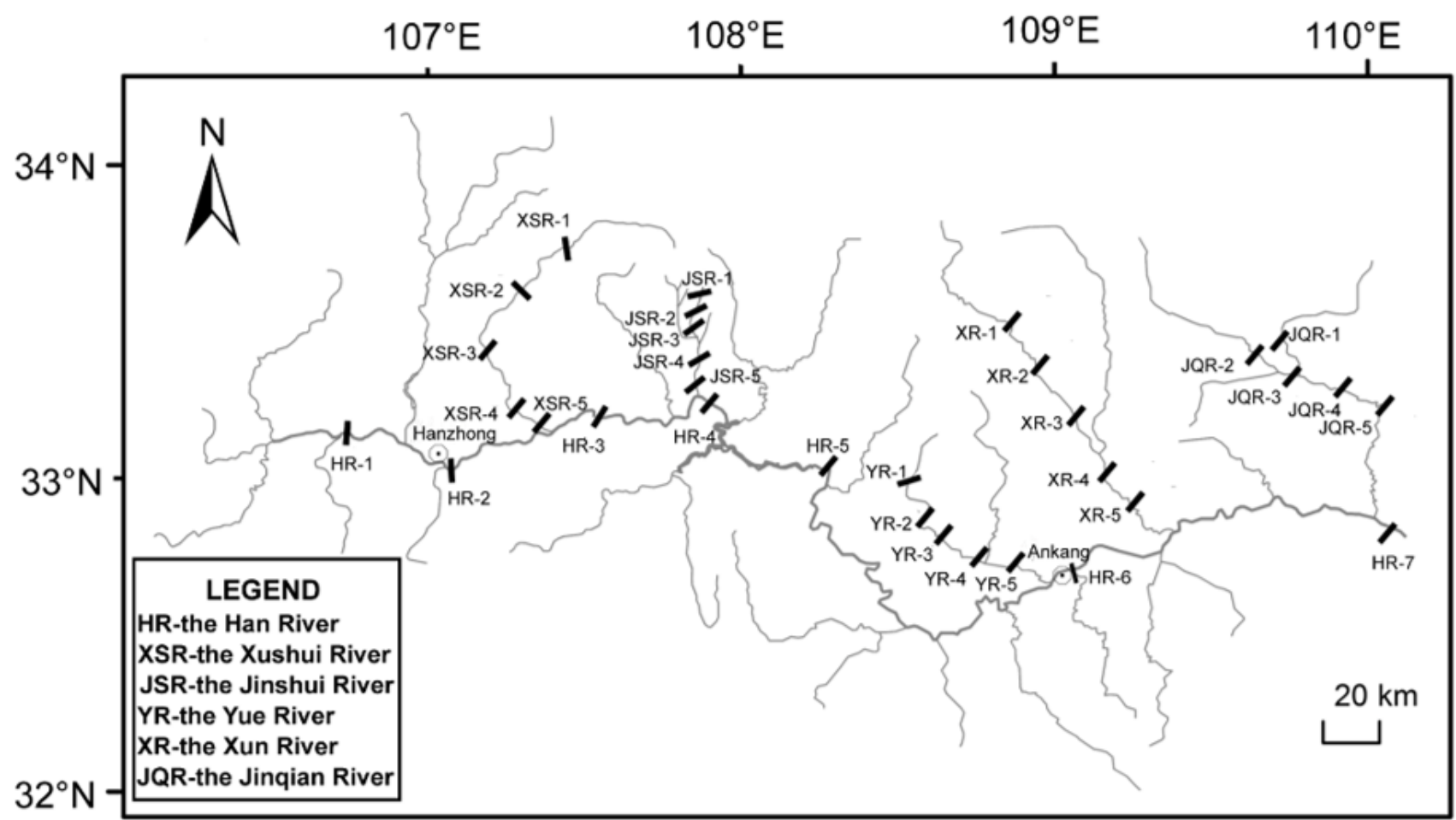

Figure 1

Distribution of sampling sections in the mainstem and tributaries of the Han River. Note: The designations employed and the presentation of the material on this map do not imply the expression of any opinion whatsoever on the part of Research Square concerning the legal status of any country, territory, city or area or of its authorities, or concerning the delimitation of its frontiers or boundaries. This map has been provided by the authors. 

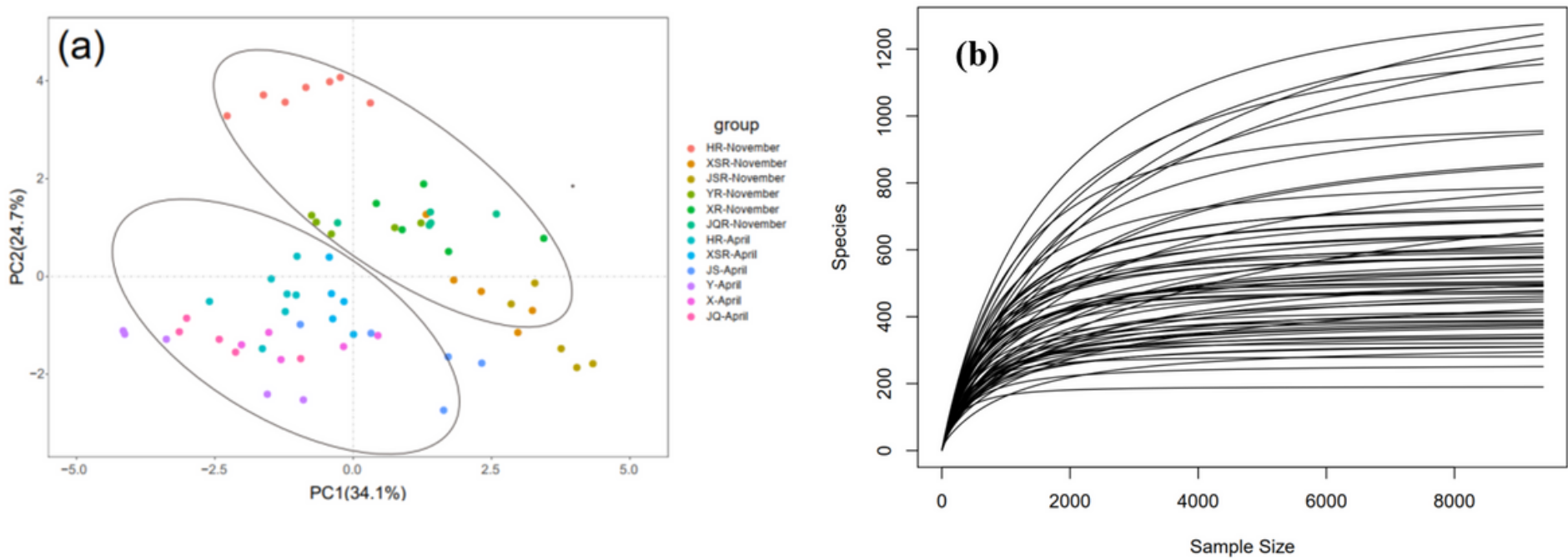

(c)

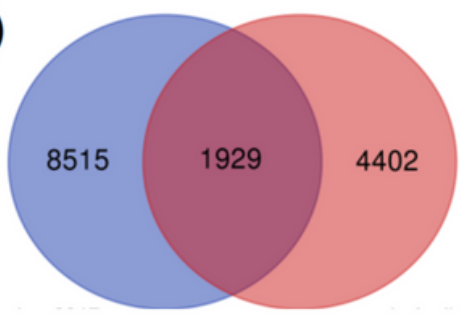

\section{Figure 2}

(a) PCA ordination of the physico-chemical parameters in the Han River and its tributaries. (b) Rarefaction curves of bacterial richness of each sample (c) Venn diagram showing the number of OTUs that are unique and shared between two sampled months. 
(a)

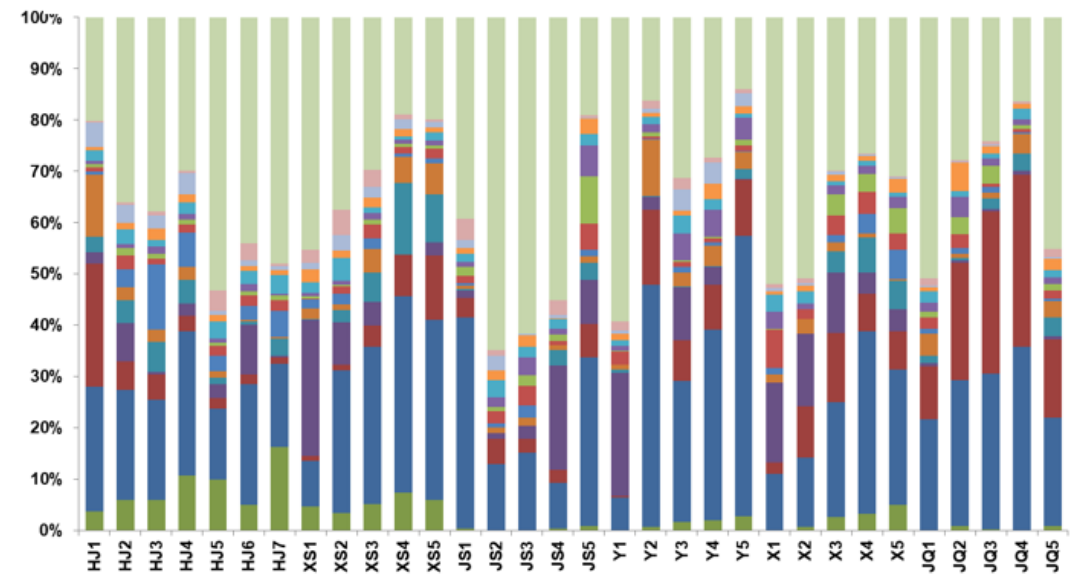

(b)

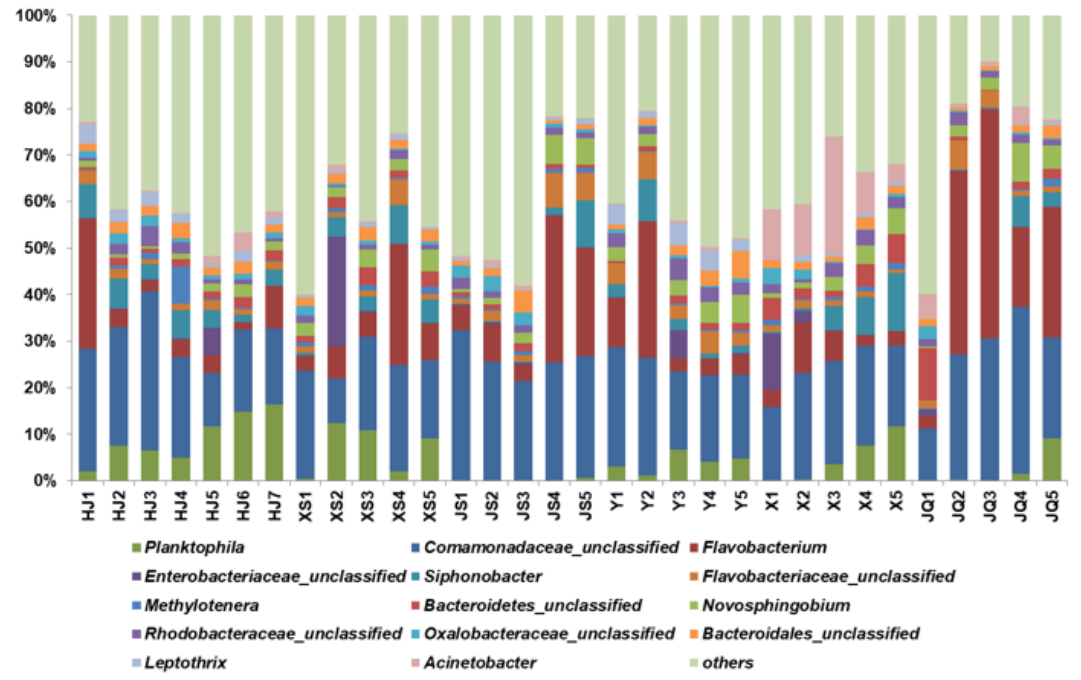

Figure 3

Genus-level taxonomic composition of the bacterioplankton communities in the mainstem and tributaries of the Han River: (a) in November 2017, (b) in April 2018 (Bacterial taxa with less than 1\% of mean relative abundance are classified as others) 


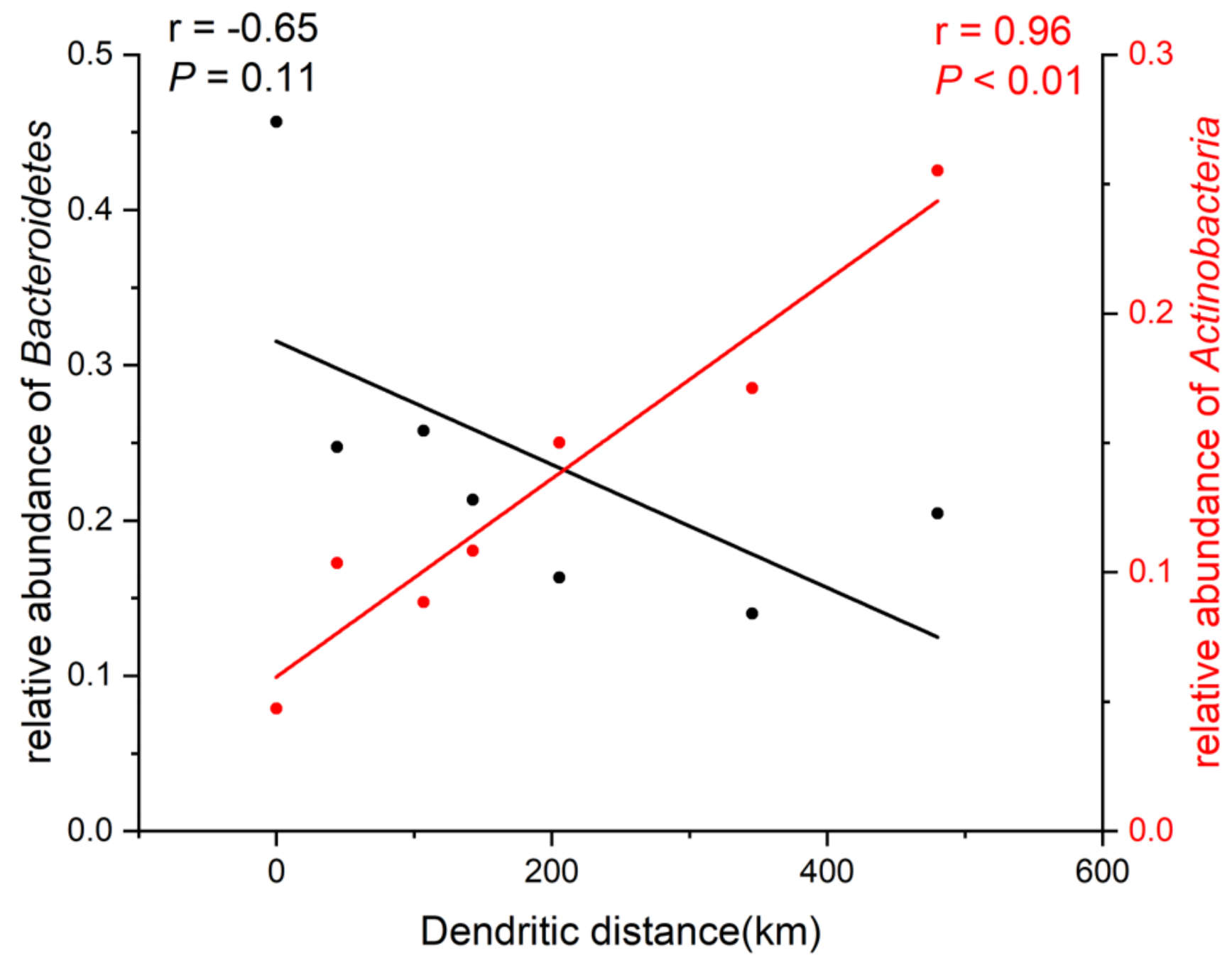

Figure 4

Pearson correlation between dendritic distance (river length) and relative abundance of Bacteroidetes and Actinobacteria in the mainstream
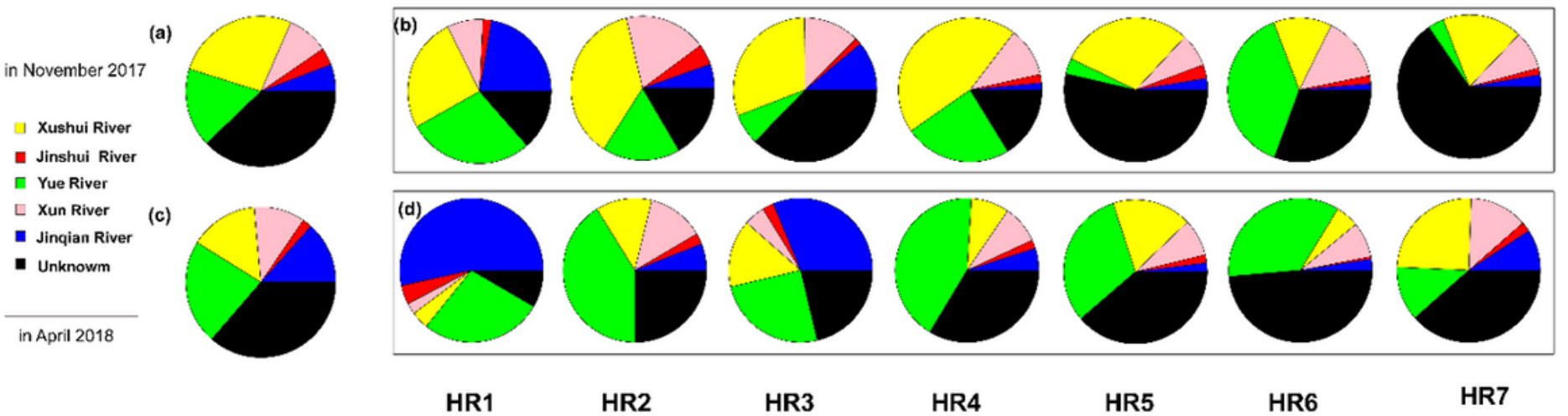

Figure 5

SourceTracker proportion estimates for the microbial community in the mainstream that came from its tributaries (a, c) Han River, (b, d) different sections 


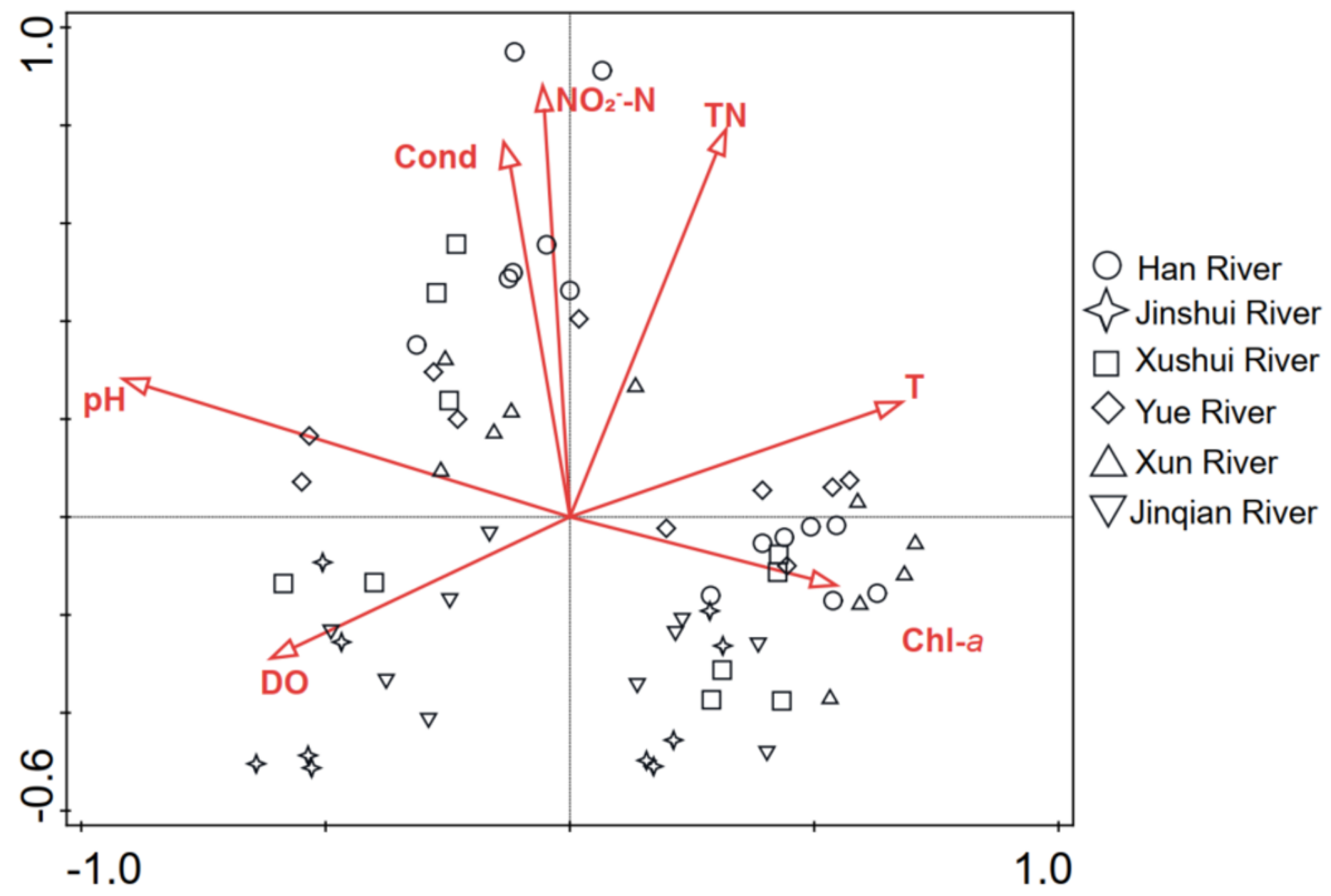

Figure 6

Redundancy analysis (RDA) of bacterioplankton (OTU)and environmental parameters 